\title{
CARACTERIZAÇÃO DO GENE DO ESTRESSE SUÍNO
}

\author{
CHARACTERIZATION OF THE SWINE STRESS GENE
}

\author{
Reginaldo Gaspar Bastos ${ }^{1}$ João Carlos Deschamps ${ }^{2}$ Odir Antônio Dellagostin ${ }^{3}$
}

\section{- NOTA -}

\section{RESUMO}

O gene do estresse suino foi caracterizado em 59 animais das raças Landrace, Large White, Duroc e cruzas destas raças com a Pietran, através da análise do ácido desoxirribonucléico (DNA) amplificado por reação em cadeia da polimerase (PCR) e clivado com endonuclease de restrição. Como fonte de DNA foi utilizado sangue, sêmen e foliculo piloso, sendo que, este último revelou-se um modo rápido e não-invasivo de obtenção de amostra que viabiliza a execução da técnica a qualquer animal dentro do sistema de produção. A freqüência genotípica foi de 0,73 para $N N, 0,26$ para $\mathrm{Nn}$ e 0,01 para $n$ n.

Palavras-chave: gene do estresse, suíno, análise de DNA.

\section{SUMMARY}

The porcine stress gene was characterized from 59 animals (Landrace, Large White, Duroc and Pietran) through analysis of deoxyribonucleic acid (DNA) amplified by polymerase chain reaction $(P C R)$ and digested with a restriction endonuclease. Blood, semen and plucked hair were used as source of DNA. The use of plucked hair is fast and non-invasive method that can be used for any animal within the production system. The genotype frequency was 0.73 to $\mathrm{NN}, 0.26$ to $\mathrm{Nn}$ and 0.01 to $\mathrm{nn}$.

Key words: stress gene, swine, DNA analysis

O gene do estresse suíno (gene hal) está localizado no cromossomo 6 e codifica para os recep- tores ryanodine, os quais são proteínas que atuam como canais liberadores de cálcio do retículo sarcoplasmático do músculo esquelético (OTSU et al., 1991). O gene hal em homozigose recessiva (nn) determina o aparecimento da Síndrome do Estresse Suíno (PSS), sendo que o mesmo gene em heterozigose (Nn) mantem relação com a diminuição da qualidade de carne (KOLNT et al., 1993; POMMIER \& HOUDE, 1993; SMET et al., 1996). A principal manifestação post-mortem da síndrome é o aparecimento da característica de carne pálida, macia (soft) e exudativa (PSE) (SMET et al., 1996). Comparações feitas entre seqüências de cDNA do gene hal de animais suscetíveis a PSS com animais normais demonstraram uma mutação na posição do nucleotídeo 1843. Nesta posição em animais suscetíveis há a troca de uma citosina $(C)$ por uma timina $(T)$, com isto ocorre a alteração do resíduo de amino-ácido 615 , que passa de uma arginina a uma cisteina (FUJJl et al., 1991; OTSU et al., 1991). Os canais liberadores de cálcio alterados tornam-se hipersensíveis ao estímulo nervoso e abrem-se facilmente, ficando seu fechamento inibido. Conseqüentemente há um aumento na concentração de cálcio no citosol, ocasionando contração muscular, hipertermia, taquicardia, acidose metabólica e respiratória devido ao aumento da

\footnotetext{
${ }^{1}$ Mestrando em Zootecnia - UFPEL/CNPq - Centro de Biotecnologia, Universidade Federal de Pelotas (UFPEL), Campus Universitário, Prédio 19, CP 354, 96010-900, Pelotas/RS. E-mail: rgbastos@ufpel.tche.br. Autor para correspondência.

${ }^{2}$ Professor Adjunto, Faculdade de Veterinária, Centro de Biotecnologia, UFPEL.

${ }^{3}$ Professor Adjunto, Instituto de Biologia, Centro de Biotecnologia, UFPel.
}

Recebido para publicaç̃o em 18.08.97. Aprovado em 15.10.97 
glicólise anaeróbica, aumento na concentração de ácidos graxos e catecolaminas circulantes, sendo que a morte se dá de 4 a 6 minutos depois do aparecimento dos sintomas (LOUIS et al., 1990; SHEN et al., 1992).

A caracterização do genótipo do gene hal com endonuclease de restrição é uma técnica rápida e segura e além disso, é a única maneira de identificar animais heterozigotos (Nn) (FUJJ et al., 1991; SHEN et al., 1992; HOUDE et al., 1993; REMPEL et al., 1993). A análise com endonuclease de restrição é baseada no fato de que em animais suscetíveis ocorre a deleção do sítio de clivagem da enzima $C f o$ I (GIBCO BRL). Sendo assim, o trabalho teve por objetivo a otimização da técnica de caracterização e a determinação do genótipo do gene hal em suínos.

Foram coletadas amostras de pêlo e sêmen de animais do Centro Agropecuário da Palma/UFPEL e de sangue de animais de abatedouro da região de Pelotas. Tais amostras foram selecionados aleatoriamente entre animais das raças Landrace, Large White, Duroc e animais cruzas destas raças com a Pietran.

Para a extração de DNA genômico a partir de sangue e sêmen foi utilizado o protocolo descrito por SAMBROOK et al. (1989). Para a extração a partir de folículo piloso, foi utilizado o protocolo descrito por BAUEROVÄ et al. (1996) o qual utiliza $0,4 \mathrm{mg} / \mathrm{ml}$ de proteinase $\mathrm{K}$, e o protocolo descrito por DISSING et al. (1996) que utiliza apenas $\mathrm{NaOH}$-Tris.

Foi amplificado por reação em cadeia da polimerase (PCR) um fragmento específico de 81 pares de bases $(\mathrm{pb})$ do gene hal. A seqüência de "primers" utilizada foi a descrita por FUJJI et al. (1991). Foi utilizado um termociclador "Thermal Reactor" (HYBAID) onde foram executados 35 ciclos compreendendo desnaturação a $95{ }^{\circ} \mathrm{C}$ por 1 minuto, anelamento a $56^{\circ} \mathrm{C}$ por 1 minuto e extensão a $72^{\circ} \mathrm{C}$ por 1 minuto.

Uma alíquota do produto do PCR $(5 \mu \mathrm{l})$ foi digerida com a enzima $C f o \mathrm{I}$ ( $5 \mathrm{U}$ por amostra), por 3 horas a $37^{\circ} \mathrm{C}$, e após a digestão as amostras foram analisadas por eletroforese em gel de agarose a $4 \%$. As freqüências genotípicas e alélicas foram determinadas através de contagem direta.

Os resultados obtidos revelaram que a análise do DNA por PCR, seguido por digestão com endonuclease de restrição para determinar o genótipo do gene hal, é uma técnica rápida e eficiente, que torna possível a identificação tanto de animais homozigotos recessívos, como também de heterozigotos (FUJJI et al., 1991). A Figura 1 mostra que animais normais, após a digestão, apresentam duas bandas de DNA no gel de agarose. Isto se deve ao fato de que nestes animais há a presença do sítio de clivagem da

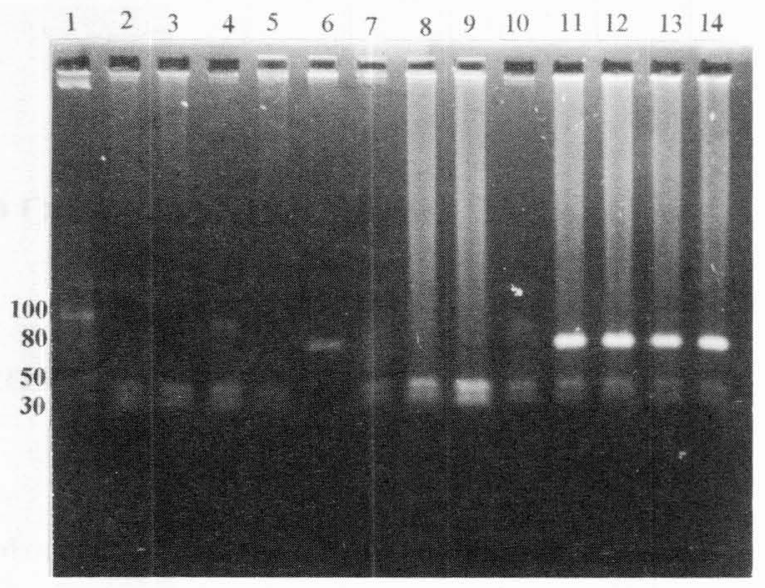

Figura 1 - Linha 1 - 10 bp DNA Ladder (GIBCO-BRL). Linhas 2, 3, 5, 7, 8 e 9 - homozitos normais Linhas $4,10,11,12,13$ e 14 - heterozigotos. Linha 5 - homozito recessivo.

endonuclease $C f o$ I. Por outro lado, animais homozigotos recessivos apresentam uma única banda devido a ausência do sítio de clivagem. Conseqüentemente, os animais heterozigotos apresentam três bandas de DNA (OTSU et al., 1991; FUJJI et al., 1991).

A utilização de folículo piloso para a extração de DNA genômico, constitui-se em um método não invasivo que viabiliza a execução da técnica a qualquer animal dentro do sistema de produção (BAUEROVÁ et al., 1996). A extração de DNA de folículo piloso através do método $\mathrm{NaOH}$-Tris permite a obtenção de uma quantidade suficiente de DNA genômico para o PCR a partir de 20 folículos, sendo que o processo de extração não leva mais do que 5 minutos. Além disso, a técnica não necessita de tampões de lise, proteinase ou centrifugações (DISSING et al., 1996).

Os resultados apresentados na Tabela 1 mostram que dos 68 animais investigados, 18 são

\begin{tabular}{|c|c|c|c|c|}
\hline \multirow[t]{2}{*}{ Animais } & \multirow[t]{2}{*}{$\mathrm{N}^{\circ}$} & \multicolumn{3}{|c|}{ Freqüência Genotípica } \\
\hline & & $\mathrm{NN}$ & $\mathrm{Nn}$ & $\mathrm{nn}$ \\
\hline Landrace (L) & 7 & 0,72 & 0,28 & - \\
\hline Large White (LW) & 4 & 1,00 & - & - \\
\hline Duroc (D) & 6 & 0,83 & 0,17 & - \\
\hline $\begin{array}{c}\text { Lx Lw } x \text { D x } \\
\text { Pietran }\end{array}$ & 51 & 0,68 & 0,30 & 0,02 \\
\hline Total & 68 & 0,73 & 0,26 & 0,01 \\
\hline
\end{tabular}


heterozigotos e um apresentou-se como homozigoto recessivo. Estes resultados referem-se a amostras de animais os quais foram utilizados para otimizar a técnica de caracterização do gene do estresse suíno, segundo as condições do Laboratório de Biologia Molecular, do Centro de Biotecnologia, da Universidade Federal de Pelotas, portanto, não pode ser feita nenhuma inferência quanto à prevalência do gene do estresse em suinos da região de Pelotas.

\section{REFERÊNCIAS BIBLIOGRÁFICAS}

BAUEROVÄ. M., VASICEK, D.. UHRIN, P., et al. Detection of malignant hyperthermia in pigs by DNA-test using plucked hair as a source of DNA. Pigs News Information, v. 6, p. 109-111. 1996.

DISSING, J., RUDBECK, L., MARCHER, H. A five minute procedure for extration of genomic DNA from whole blood, semen and forensic stains for PCR. Advances in Forensic Haemogenetics. Spring-Verlag, New York. Carracedo Editors, p. 269-271, 1996.

FUJJI, J., OTSU, K., ZORZATO, F., et al. Identification of a mutation in porcine ryanodine receptor associated with malignant hyperthermia. Science, v. 253, p. 448-451, 1991.

HOUDE. A., POMMIER, S.A., ROY, R. Detection of the ryanodine receptor mutation associated with malignant hyperthermia in purebred swine populations. Journal of Animal Science, v. 71, p. 1414-1418, 1993

KLONT, R.E., LAMBOOY, E., van LOGTESTIJIN, J.G. Effect of preslaughter anesthesia on muscle metabolism and meat quality of pigs of different halothane genotypes. Journal of Animal Science, v. 71, p. 1477-1485, 1993.

LOUIS, C.F., GẢLLANT, E.M. REMPLE E., et al. Malignant hyperthermia and porcine stress syndrome: a tale of two species. Pig News Information, v.1 1, p.341-344. 1990

OTSU. K., KHANNA, V.K., ARCHIBALD, A.L., et al. Cosegregation of porcine malignant hyperthermia and a probable causal mutation in the skeletal muscle ryanodine receptor gene in backcross families. Genomics, v. 11, p. 744, 1991.

POMMIER, S.A., HOUDE, A. Effect of the genotype malignant hyperthermia as determined by a restriction endonuclease assay on the quality characteristics of commercial pork loins. Journal of Animal Science, v. 71, p. 420-425, 1993.

REMPEL, W.E., LU, M., KANDELGY, S., et al. Relative accuracy of the halothane challenge test and a molecular genetic test in detecting the gene for porcine stress syndrome. Journal of Animal Science, v. 71, p. 1395-1399, 1993.

SHEN, H., LAHUCKY, R., KOVAC, L, et al. Comparasion of HAL gene status with 32P NMR-determined muscle metabolites and with $\mathrm{Ca}$ sequestration activity of anoxia-challenged muscle from pigs homozygous and heterozygous for porcine stress syndrome. Pigs News Information, v. 13, p. 105-109. 1992

SMET, S.M., PAUWELS, H., DE BIE, S., et al. Effect of halothan genotype, breed, feed withdrawal, and lairage on pork quality of Belgian slaugter pigs. Journal of Animal Science, v. 74, p. 1854-1863, 1996.

SAMBROOK, J., FRITSCH, E.F. AND MANIATIS. Molecular Cloning: A Laboratory Manual. 2. ed. New York: Cold Spring Harbor Laboratory, 1989. 9.16-9.23.

Ciência Rural, v. 28, n. 2, 1998. 